\title{
Two Families with SOD1 (L144F) and C9orf72 Gene Mutations and an Overview of Amyotrophic Lateral Sclerosis
} SOD1 (L144F) ve C9orf72 Gen Mutasyonları Saptanan Íki Aile ve Amiyotrofik Lateral Skleroza Genel Bakış

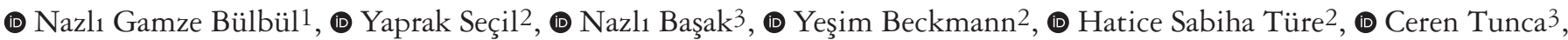
(1) Aslihan Özoğuz 3

${ }^{1}$ Mus State Hospital, Clinic of Neurology, Mus, Turkey 2Katip Celebi University Faculty of Medicine, Ataturk Training and Research Hospital, Clinic of Neurology, Izmir, Turkey

${ }^{3}$ Bogazici University Faculty of Medicine, Department of Molecular Biology and Genetics, Istanbul, Turkey

\begin{abstract}
Amyotrophic lateral sclerosis (ALS) is a fatal neurodegenerative disease that affects both upper and lower motor neurons and its etiology is not fully understood. The incidence of ALS is 2-3/100,000 people in the world. Although ALS occurs sporadically in most patients, 5-10\% of patients are thought to have genetic inheritance. The most common gene mutations are C9orf 72 , superoxide dismutase 1 (SOD1), TDP43, FUS, and ubiquilin 2. In our study, within the light of the literature, we wanted to represent three patients with familial ALS who had SOD1 and C9orf72 gene mutations, who were observed in detail in our clinic in terms of clinical, electromyographic, and genetic findings.
\end{abstract}

Keywords: Familial amyotrophic lateral sclerosis, SOD1, C9orf 72

Öz

Amiyotrofik lateral skleroz (ALS) üst ve alt motor nöronları etkileyen fatal seyirli nörodejeneratif bir hastalıktır ve etiyolojisi tam olarak bilinmemektedir. Hastalık, dünyada her 100.000 kişinin 2 ila 3’ünde görülmektedir. ALS olgularının çoğu sporadik olsa da, yaklaşık \%5-10’unda genetik kalıtım öyküsü vardır. En fazla rastlanan gen mutasyonları C9orf72, süperoksit dismutaz 1 (SOD1), TDP43, FUS ve ubiquilin 2 olarak bilinmektedir. Çalışmamızda klinik, elektromiyografi ve genetik bulgularını kliniğimizde detaylı olarak gözlemleyebildiğimiz, SOD1 ve C9orf72 gen mutasyonu pozitif üç ailesel ALS olgusunu literatür eşliğinde sunmak istedik.

Anahtar Kelimeler: Ailesel amiyotrofik lateral skleroz, SOD1, C9orf72

\section{Introduction}

Amyotrophic lateral sclerosis (ALS), also known as Charcot or Lou Gehrig's disease, is the most common motor neuron disease in the world (1). ALS can be sporadic (SALS) or familial (FALS). Our knowledge about ALS has increased significantly with developments in genetics. It is still controversial as to how a genetic predisposition and environmental factors come together and cause ALS (2). There is no clinical difference between SALS and FALS, but patients with FALS present with symptoms of ALS approximately 10 years earlier. In the pathogenesis of ALS, many mechanisms involving genes, protein inclusions, and cellular dyshomeostasis have been shown and still studies on these mechanisms are continuing (3). It is always challenging to diagnose ALS because no one single test or diagnostic tool is enough to diagnose ALS and its diagnosis is based on clinical presentation, progression, and the results of tests (4). We discuss three patients in view of the literature who were considered to have FALS due to clinical and electrophysiologic features, and were treated and followed up over a long period.

Address for Correspondence/Yazışma Adresi: Nazlı Gamze Bülbül MD, Mus State Hospital, Clinic of Neurology, Mus, Turkey

Phone: +90 5053104840 E-mail: nzl.gmzb@gmail.com ORCID ID: orcid.org/0000-0001-8560-0774

Received/Geliş Tarihi: 16.01.2017 Accepted/Kabul Tarihi: 07.08.2017

${ }^{\circ}$ Copyright 2018 by Turkish Neurological Society

Turkish Journal of Neurology published by Galenos Publishing House. 


\section{Case Reports}

\section{Case 1}

A 46-year-old male was admitted to our clinic with speech disturbance that began 3 weeks previously. He was unable to get his words together and express them. The findings of an electromyography (EMG) performed in another hospital were uncertainly suggestive of motor neuron disease. He had a family history of ALS and was hospitalized with a pre-diagnosis of ALS. There were no features in his medical history.

In his family history, his grandmother, uncle, father, and older brother had ALS (Table 1) (Figure 1). There was no kinship between his mother and father. In the first neurologic examination, he had mild dysarthria, a mild increase in pharynx reflex, hyperactive deep tendon reflexes, and fasciculation in the right upper extremity. Abdominal skin reflex was negative. Jaw and snout reflexes were positive. Bilateral palmomental, Hoffmann, and Babinski signs were positive. Laboratory findings were within normal limits. An otorhinolaryngologic examination for dysphagia revealed normal findings. Cranial, cervical, and lumbar magnetic resonance imaging (MRI) were normal. Nerve conduction studies were normal and fasciculation and denervation potentials were found in the left biceps and tibialis anterior (TA) muscles. Fasciculation in the right TA, pseudomyotonia in the orbicularis oris, and mild neurogenic motor unit potentials (MUP) in some muscles were found. The patient was considered as having motor neuron disease because of his clinical and EMG findings and loaded family history, and Riluzole $100 \mathrm{mg} / \mathrm{d}$ was initiated. Antidepressant treatment was added because he had symptoms of depression. There was a mild progression in a follow-up EMG performed one month later and there was no difference in an EMG performed 3 months later. Electrophysiologic examinations for evaluating dysphagia showed a mild delay in the triggering time of swallowing. The dysphagia limit was $10 \mathrm{~mL}$ (normal: $>20 \mathrm{~mL}$ ) $(5,6)$ (Figure 2, 3) and the patient was considered as having neurogenic dysphagia.

The patient became immobile in 5 years and he was admitted to hospital with respiratory failure and general worsening 6 years after diagnosis. On neurologic examination, he was conscious and cooperation was limited. He was severely dysarthric and he could say a few words. The uvula was in the midline and the pharynx reflex was mildly increased. Muscle strength was Medical Research Council (MRC) $2 / 5$ in the proximal upper extremities, 2-3/5 in the distal upper extremities, $1-2 / 5$ in the proximal lower extremities, and $2 / 5$ in the distal lower extremities. Deep tendon reflexes were

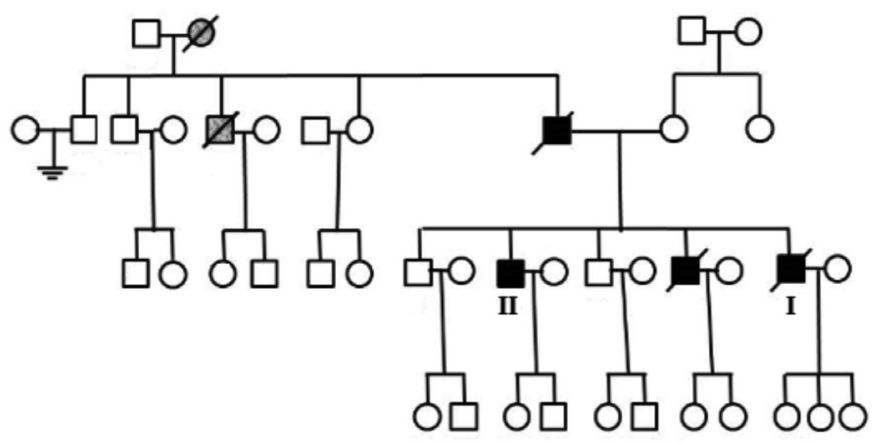

Figure 1. Pedigrees of Case 1 and 2 (marked as I and II)

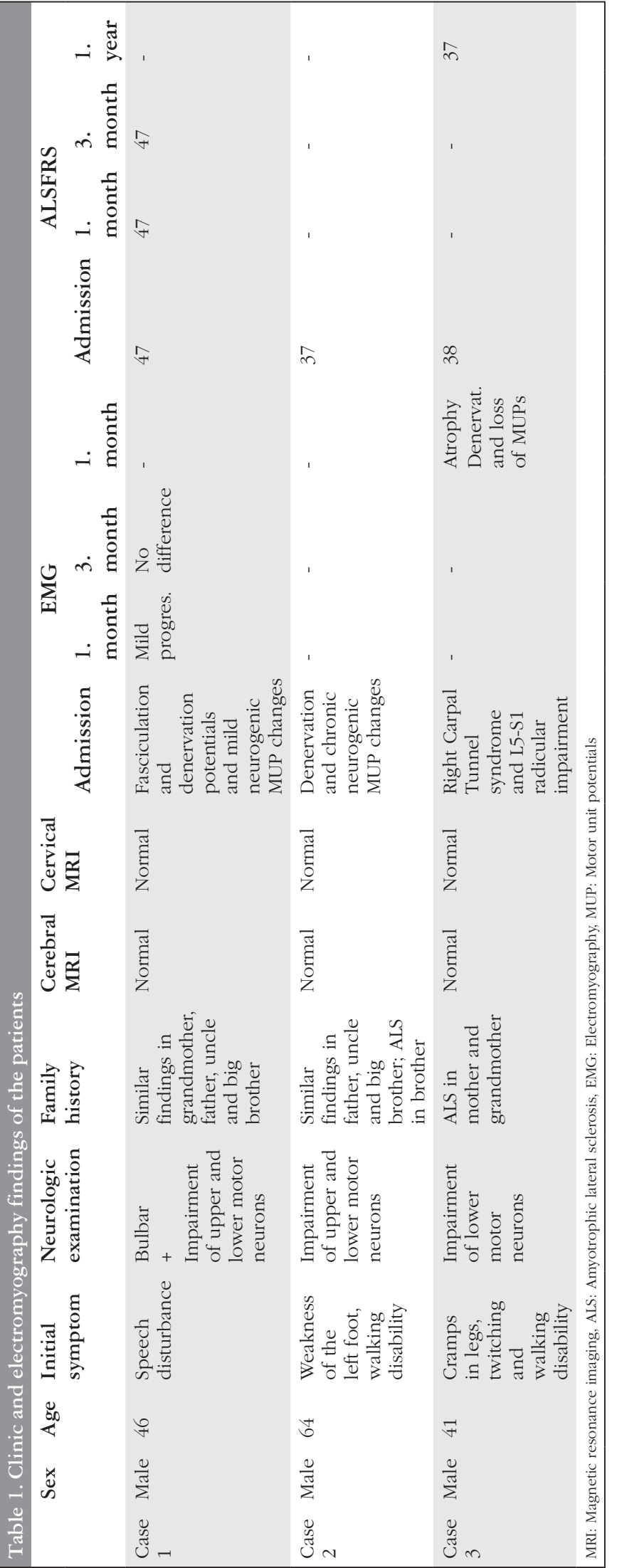




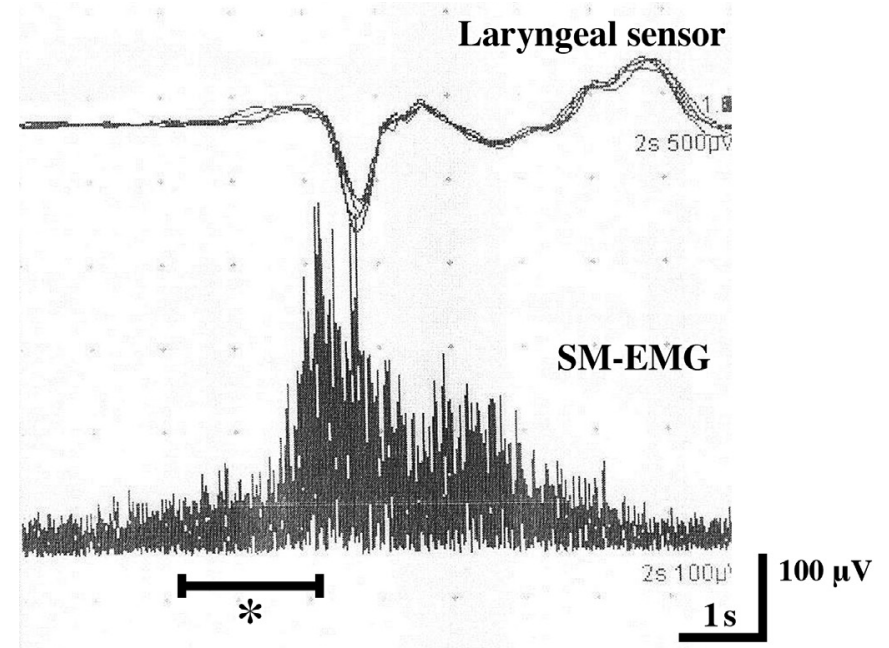

Figure 2. During swallowing $3 \mathrm{~mL}$ of water, mild delay in triggering time of swallowing marked as star-like sign

SM-EMG: Submental-electromyography

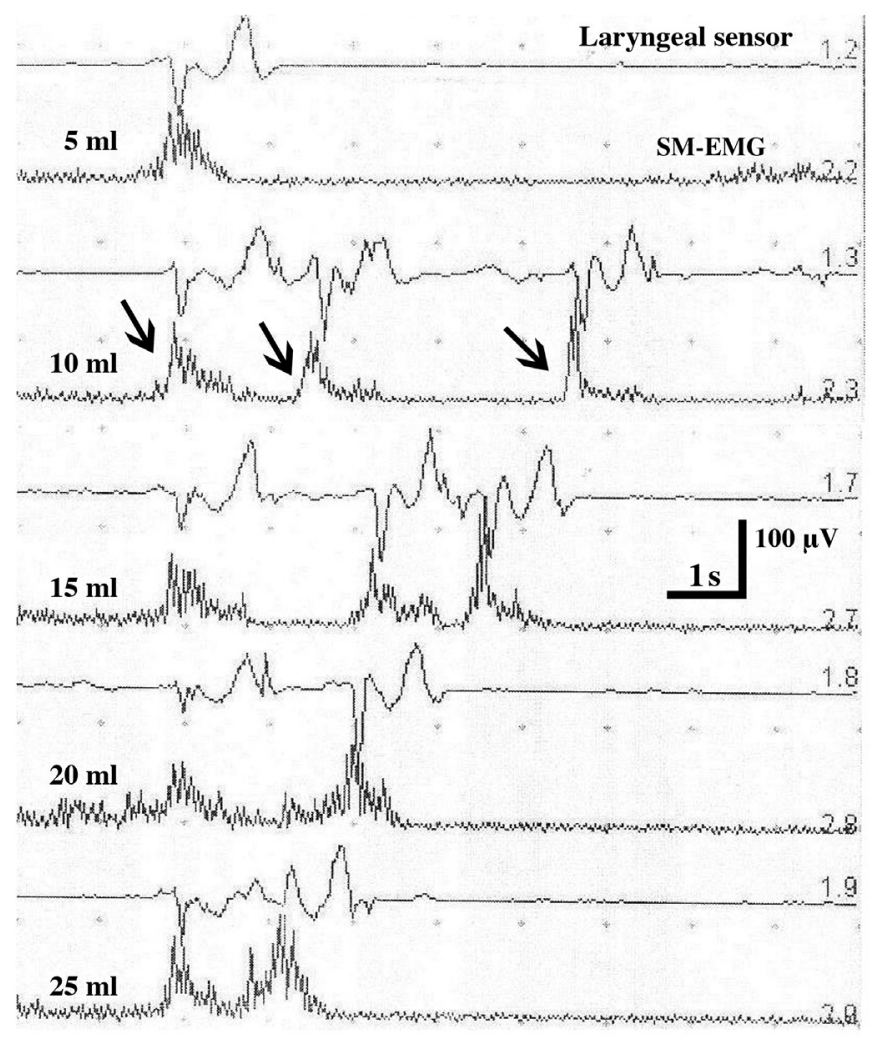

Figure 3. Larynx sensor and submental EMG recordings (10 sec, $1 \mathrm{mV}$ ) of the patient while testing of dysphagia limit during swallowing 5, 10, 15, 20 and $25 \mathrm{~mL}$ of water, respectively. Dysphagia limit of the patient is measured as $10 \mathrm{~mL}$. The patient swallows water more than $10 \mathrm{ml}$ by splitting. Normal value for healthy subjects is above $20 \mathrm{~mL}$. Arrows show swallowing by splitting

SM-EMG: Submental-electromyography hyperactive. Fasciculations were seen in the right upper extremity. Bilateral clonus, palmomental, Hoffmann, and Babinski signs were positive. The patient was intubated because of common worsening and respiratory failure, and was hospitalized in the neurology intensive care unit with a diagnosis of pneumonia. The patient was discharged with home-type mechanical ventilatory support and percutaneous endoscopic gastrostomy. After obtaining informed consent from his relatives, a blood sample was taken from the patient for a genetic investigation for the diagnosis of $F A L S$, which was sent to Bogazici University Genetic Unit. Expansion was found in the C9orf72 gene using flanking region-polymerase chain reaction $(\mathrm{PCR})$ and repeat-primed $(\mathrm{RP})-\mathrm{PCR}$, which was thought to cause the disease. The patient died at home of respiratory failure after 3 years.

\section{Case 2}

After one year, the older brother of patient 1 was admitted to our clinic with weakness of the left foot and deterioration in walking. He was aged 64 years and there were no features in his medical history. His symptoms started 11 months previously with pain in the knees, weakness, walking with a dragging left foot, and then changes in the shape of his fingers, thinning in muscles of the hand, and weakness in the right arm. The patient was sent to a neurologist by an orthopedist for foot drop to perform EMG. In the neurologic examination, his muscle strength was MRC $4+15$ in the upper extremities and he had bilateral foot drop. Thenar atrophy in the left hand, and fasciculation in the right shoulder girdle and left lower extremity were observed. Deep tendon reflexes were hyperactive in the upper extremities. The abdominal skin reflex was negative. The Babinski sign was positive in the left and reckless in the right. Laboratory findings were normal. Left peroneal motor compound muscle action potential (CMAP) was found low in EMG. Needle EMG showed distal denervation and mild chronic neurogenic MUP changes in the upper and lower extremities (predominantly left), but normal findings in cranial muscles.

Family history, clinical, and EMG findings suggested motor neuron disease and laboratory investigations were performed again. Cranial, cervical, and lumbar MRI were normal (Table 1) (Figure 1). Serologic biomarkers, tumor markers, and abdominal and thoracic CT performed for the etiologic investigation were negative or normal. A blood sample was taken from the patient for genetic investigation for the diagnosis of FALS after taking an informed consent from his relatives and sent to Bogazici University Genetic Unit. Expansion was found in the C9orf72 gene using flanking region-PCR and RP-PCR, as found in his brother, which was thought to cause the disease. He was considered as having motor neuron disease and EMG was planned for follow-up.

\section{Table 2. Clinic features of the mutations}

\begin{tabular}{|ll|} 
Mutation & Clinic features \\
SOD1- $A 4 \mathrm{~V}$ mutation & $\begin{array}{l}\text { Aggressive clinical course } \\
\text { Rapid progression }\end{array}$ \\
C90rf 72 mutation & $\begin{array}{l}\text { Sneaky clinical course } \\
\text { Marked cognitive impairment }\end{array}$ \\
& $\begin{array}{l}\text { Often bulbar impairment } \\
\text { Marked cognitive impairment }\end{array}$ \\
\hline
\end{tabular}




\section{Case 3}

A 41-year-old male was admitted to our clinic with fatigue in his legs, twitching, cramps, and walking disturbance. His symptoms had started 6 years previously and progressed in one year. There were no features in his medical history. In his family history, his mother and grandmother had been diagnosed as having ALS and died of ALS (Figure 4). Muscle twitches in the upper and lower extremities were observed. Cranial, cervical, and lumbar MRIs showed no pathology. EMG showed right carpal tunnel syndrome and needle EMG showed bilateral L5-S1 chronic radicular impairment. After one year, his symptoms worsened and weakness of the distal extremities was found in a neurologic examination. Follow-up EMG showed loss of MUPs, acute denervation in the left L5 area, and progressive radiculopathy. In the following year, his walking disability worsened and he was hospitalized for further investigation. His muscle strength was MRC $4+/ 5$ in the bilateral upper extremities and 4/5 in the bilateral flexors and extensors of the legs. Bilateral Babinski and Hoffmann reflexes were positive. Repeated EMG showed mild bilateral carpal tunnel syndrome and low left peroneal CMAP. EMG findings of cranial muscles were normal. Needle EMG showed denervation, neurogenic MUP changes, and loss of MUPs. Cranial, cervical, thorax and lumbar MRIs were normal. Detailed laboratory tests were normal. Abdominal and thorax CT and scrotal ultrasonography were normal (Table 1).

Clinical, laboratory, and EMG findings and family history of the patient suggested the diagnosis of motor neuron disease and Riluzole with a dose of $100 \mathrm{mg} / \mathrm{d}$ was initiated. Because the cramps in his legs had worsened, Lamotrigine with a dose of 50 $\mathrm{mg} / \mathrm{d}$ was added. Following one year, he was admitted to our clinic because his symptoms had worsened. On neurologic examination, he had difficulty in fine movements of the upper extremities. His muscle strength was MRC 3-4/5 in the lower extremities, he had spastic walking, his deep tendon reflexes were hyperactive and ankle clonus was bilaterally positive. Fasciculations were

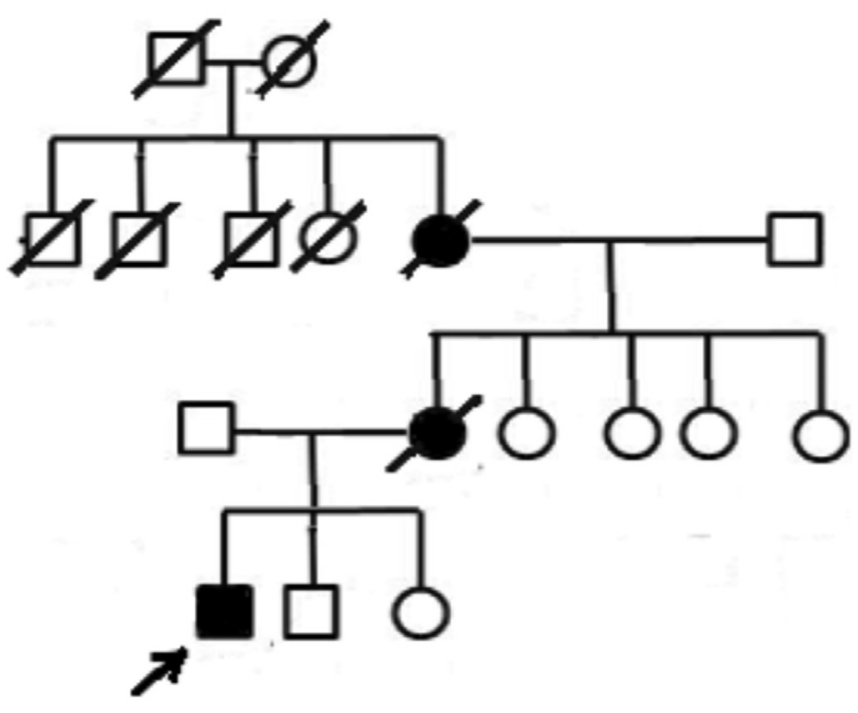

Figure 4. Pedigree of Case 3 observed widely, but there was no fasciculation in the tongue or tongue atrophy. An etiologic search for motor neuron disease was repeated. Anti Hu, Yo, Ri, CV2.1, NMA2/TA, and amphiphysin antibodies for paraneoplastic syndromes were negative. In repeated EMG, denervation potentials were observed in bilateral muscles of the upper extremities and left TA, chronic neurogenic MUP changes and loss of MUPs were seen in the same muscles and in other muscles of the lower extremities. EMG findings of the cranial muscles were normal. A genetic investigation was planned, because he had a family history of motor neuron disease, and a blood sample was sent to Bogazici University Genetic Unit after obtaining informed consent from his relatives. The gene sequence of $C 9$ orf7 2 gene was normal and a heterozygous $L 144 \mathrm{~F}$ mutation in the $5^{\text {th }}$ exon in the SOD1 gene was found, which was thought to cause the disease.

\section{Discussion}

ALS is the most common motor neuron disease in adults. It is caused by degeneration of both upper motor neurons in the primary motor cortex and lower motor neurons in the brainstem and spinal cord (7). Patients die of respiratory failure 2-3 years after the beginning of symptoms (8). The mean beginning age of the disease is 58-63 years and $40-60$ years in FALS $(7,9)$. Studies show that the initial symptoms affect lower extremities in $35 \%$ of patients, upper extremities in 30-35\%, and the trunk in 3-5\% of patients, and $18-33 \%$ of patients present with progressive bulbar palsy (10). Riluzole, a glutamate antagonist, that has been approved by the United States Food and Drug Administration increases the survival of the patient by a couple of months if initiated at the beginning of the disease (7).

One test or diagnostic tool is generally not enough for the diagnosis of ALS and clinical findings should be followed up with the tests available. Although our patients had mild clinical findings at first and did not meet all the EMG criteria, we considered motor neuron disease as a diagnosis because of their family history of motor neuron disease.

Approximately $5-10 \%$ of patients with ALS are thought to have FALS and the remainder has SALS. FALS often shows as autosomal dominant but rarely there is an X-linked or autosomal recessive inheritance pattern $(11,12)$. The most common gene mutations related with FALS are C9orf72, SOD1, TDP43, FUS and ubiquilin 2 (UBQLN2). Mutations in the ALS2, senataxin, dynactin, angiogenin, optineurin, and spatacsin genes are relatively rare mutations related with $F A L S(12,13,14)$.

A mutation in the SOD1 gene was the first reported mutation as a cause of ALS. The SOD1 enzyme $(\mathrm{Cu}-\mathrm{Zn}$ superoxide dismutase) is a homodimeric enzyme that consists of 153 amino acids and is found in the cytoplasm and mitochondrial membrane. It leads to the transformation of superoxide radicals to oxygen and hydrogen peroxide. More than 170 mutations that cause ALS have been defined in the SOD1 gene to date and mutations in the SOD1 gene cause the disease in $20 \%$ of patients with FALS and $1-5 \%$ of patients with SALS $(7,13,14)$. The frequency of SOD1 mutations is reported as $23.5 \%$ in Nordic countries, $23.4 \%$ in the United States of America, 21\% in England, 14.3\% in France, and $12.2 \%$ in Turkey $(12,15)$. The most common mutations are $D 90 A, A 4 V$, and $G 93 A$ mutations (13). Phenotypic differences 
in patients with SOD1 mutations are observed. For example, the $A 4 \mathrm{~V}$ mutation, which is common in North America, is characterized by an aggressive clinical course and results in death in one year after the beginning of symptoms. Patients with the D90A mutation present with a sneaky clinical course, have more cognitive impairment, and die of respiratory failure in 10 years (Table 2). Antibodies and antisense oligonucleotides have been developed against SOD1 mRNA to decrease gene expression and decrease the production of pathogenic mutant protein, these are new treatment strategies that are being investigated in trials $(8,11)$.

Another gene called the C9orf72 gene is located in the $9^{\text {th }}$ chromosome and its function is still not known (7). The repetition of GGGGCC hexanucleotides, which do not code a protein in the gene, results in mutation (7). This mutation is the most common genetic cause of ALS and frontotemporal lobar degeneration (FTLD). Studies show that ALS and FTLD symptoms present at the same time in impaired families, their symptoms overlap, and they share the same genetic mutation $(8,14,16)$. The GGGGCC repetition sequence is shorter than 25 units in healthy subjects, whereas it increases up to 800-4400 in patients with ALS and FTLD. The C9orf 72 hexanucleotide repetition is seen in $40 \%$ of patients with FALS, $25 \%$ of patients with FTLD, and $90 \%$ of families with FTLD and ALS. The frequency of the mutation is higher in Europe and North America compared with Asian countries (14,17). Some studies showed that $C 9$ orf 72 repeats could be found in patients with Parkinson's disease, Alzheimer's disease, progressive supranuclear palsy, and corticobasal degeneration, in addition to FTLD and ALS $(8,18)$. Presenting with bulbar symptoms and marked cognitive impairment were shown as features of patients with C9orf72 (+) ALS in some studies (Table 2) $(8,17)$. The initial symptom of Case 1 was dysarthria who had the C9orf 72 mutation. Antisense oligonucleotides against $C 90$ rf72 as against the $S O D 1$ gene are being investigated as new treatment modalities in ALS (11).

A multicenter study performed in 477 patients with ALS (116 of whom had FALS) researched the genetic mutations in Turkey and found the following rates: C9orf72 (18\%), SOD1 (12.2\%), FUS $(5 \%)$, TARDBP $(3.7 \%)$ and UBQLN2 (2.4\%). Turkey has a heterogeneous ethnic structure. Consanguineous marriages and large families increase the phenotypic heterogeneity within and inter families. Investigations of genomic diversity in Turkey could help us to understand the molecular mechanisms of the disease and lead to the development of new treatment modalities (12).

Genetic counseling for ALS is reliable if its penetrance is exactly known. Therefore, studies on asymptomatic mutation carriers are important. Early detection of gene mutations can help us avoid the treatable complications of the disease and lead to early diagnosis and treatment of relatives of patients who are under risk (18).

Our knowledge has significantly increased since the first description of the ALS gene 20 years ago and will continue to develop. Genetic studies with large patient groups are important to help us understand neurodegeneration. Discovering rare variants allows us to solve the entire genomic structure and to determine the pathogenesis of motor neuron degeneration. Perhaps, in 20 years, gene therapies of ALS will be available.

\section{Acknowledgements}

Thanks to the Suna and İnan Kıraç Foundation for their technical support and Güneş Birdal for her contributions to the paper.

\section{Ethics}

Informed Consent: Consent form was filled out by all participants.

Peer-review: Externally and internally peer-reviewed.

\section{Authorship Contributions}

Concept: N.G.B., Y.S., Design: N.G.B., Y.S., Y.B., Data Collection or Processing: N.G.B., Y.S., Y.B., N.B., A.Ö., C.T., H.S.T., Analysis or Interpretation: N.G.B., Y.S., N.B., Literature Search: N.G.B., Y.S., Writing: N.G.B.

Conflict of Interest: No conflict of interest was declared by the authors.

Financial Disclosure: The authors declared that this study received no financial support.

\section{References}

1. Pratt AJ, Getzoff ED, Perry JJ. Amyotrophic lateral sclerosis: update and new developments. Degener Neurol Neuromuscul Dis 2012;2012:1-14.

2. Al-Chalabi A, Hardiman O. The epidemiology of ALS: a conspiracy of genes, environment and time. Nat Rev Neurol 2013;9:617-628.

3. Wijesekera LC, Leigh PN. Amyotrophic lateral sclerosis. Orphanet J Rare Dis 2009; $4: 3$.

4. Hardiman O,van den Berg LH, Kiernan MC. Clinical diagnosis and management of amyotrophic lateral sclerosis. Nat Rev Neurol 2011;7:639649

5. Ertekin C, Aydogdu I, Yüceyar N, Kiylioglu N, Tarlaci S, Uludag B. Pathophysiological mechanisms of oropharyngeal dysphagia in amyotrophic lateral sclerosis. Brain 2000;123:125-140.

6. Ertekin C, Aydoğdu I, Yüceyar N. Piecemeal deglutition and dysphagia limit in normal subjects and in patients with swallowing disorders. J Neurol Neurosurg Psychiatry 1996;61:491-496.

7. Ingre C, Roos PM, Piehl F, Kamel F, Fang F. Risk factors for amyotrophic lateral sclerosis. Clin Epidemiol 2015;7:181-193.

8. Renton AE, Chiò A, Traynor BJ. State of play in amyotrophic lateral sclerosis genetics.Nat Neurosci 2014;17:17-23

9. Chiò A, Calvo A, Mazzini L, Cantello R, Mora G, Moglia C, Corrado L, D'Alfonso S, Majounie E, Renton A, Pisano F, Ossola I, Brunetti M, Traynor BJ, Restagno G; PARALS. Extensive genetics of ALS: a population-based study in Italy. Neurology 2012;79:1983-1989.

10. Andersen PM, Nilsson P, Keränen ML, Forsgren L, Hägglund J, Karlsborg M, Ronnevi LO, Gredal O, Marklund SL. Phenotypic heterogeneity in motor neuron disease patients with $\mathrm{CuZn}$-superoxide dismutase mutations in Scandinavia. Brain 1997;120:1723-1737.

11. Robberecht W, Philips T. The changing scene of amyotrophic lateral sclerosis. Nat Rev Neurosci 2013;14:248-264.

12. Özoğuz A, Uyan Ö, Birdal G, Iskender C, Kartal E, Lahut S, Ömür Ö, Agim ZS, Eken AG, Sen NE, Kavak P, Sayg1 C, Sapp PC, Keagle P, Parman Y, Tan E, Koç F, Deymeer F, Oflazer P, Hanağası H, Gürvit H, Bilgiç B, Durmuş H, Ertaş M, Kotan D, Akalın MA, Güllüoğlu H, Zarifoğlu M, Aysal F, Döşoğlu N, Bilguvar K, Günel M, Keskin Ö, Akgün T, Özçelik H, Landers JE, Brown $\mathrm{RH}$, Başak AN. The distinct genetic pattern of ALS in Turkey and novel mutations. Neurobiol Aging 2015;36:1764.e9-18.

13. Kaur SJ, McKeown S R, Rashid S. Mutant SOD1 mediated pathogenesis of Amyotrophic Lateral Sclerosis. Gene 2016;577:109-118.

14. Laferriere F, Polymenidou M. Advances and challenges in understanding the multifaceted pathogenesis of amyotrophic lateral sclerosis. Swiss Med Wkly 2015;145:w14054.

15. Andersen PM, Sims KB, Xin WW, Kiely R, O'Neill G, Ravits J, Pioro E, Harati Y, Brower RD, Levine JS, Heinicke HU, Seltzer W, Boss M, Brown 
$\mathrm{RH}$ Jr. Sixteen novel mutations in the $\mathrm{Cu} / \mathrm{Zn}$ superoxide dismutase gene in amyotrophic lateral sclerosis: a decade of discoveries, defects and disputes. Amyotroph Lateral Scler Other Motor Neuron Disord 2003;4:62-73.

16. Mackenzie IR, Frick P, Neumann M. The neuropathology associated with repeat expansions in the C9ORF72 gene. Acta Neuropathol 2014;127:347357.
17. Iguchi Y, Katsuno M, Ikenaka K, Ishigaki S, Sobue G. Amyotrophic lateral sclerosis: an update on recent genetic insights. J Neurol 2013;260:29172927.

18. Woollacott IO, Mead S. The C9ORF72 expansion mutation: gene structure, phenotypic and diagnosticissues. Acta Neuropathol 2014;127:319-332. 